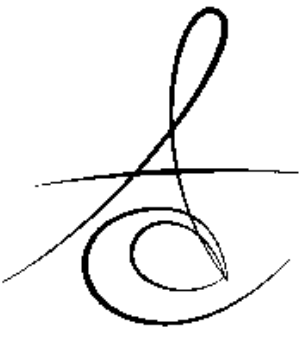

\section{EFFECTS OF TWO DIFFERENT PERIODONTAL RECALL PROGRAMS ON ORAL HYGIENE AND GINGIVAL HEALTH OF PATIENTS UNDERGOING FIXED ORTHODONTIC TREATMENT: A YEAR FOLLOW UP}

\section{SABİT ORTODONTİK TEDAVİ GÖREN HASTALARDA İKİ FARKLI PERİODONTAL TAKIP PROGRAMININ ORAL HIJYEN VE DIŞETI SAĞLIĞINA ETKİSI: BİR YILLIK TAKİP}

\section{Dr. Öğr. Üyesi Filiz USLU*}

Doç. Dr. Oğuz KösE ${ }^{* * *}$

Uzm. Dt. Tuba KöSE**

Makale Kodu/Article code: 3788

Makale Gönderilme tarihi: 06.07.2018

Kabul Tarihi: 12.12 .2018

\section{ABSTRACT}

Aim: To compare the effects of two different periodontal recall programs on gingival health of patients undergoing fixed orthodontic treatment.

Materials and Methods: Fifty-four adolescents (25 female and 29 male, mean age is $15,19 \pm 0,4$ years), who will be undergoing fixed orthodontic treatment, were divided into two equal groups (Group 1, Group 2). Group 1 was selected for periodontal recall program consisting of three-month intervals, and Group 2 was selected for periodontal recall program consisting of four-week intervals. The periodontal parameters (plaque index [PI], gingival index [GI] and bleeding on probing $[\mathrm{BOP}]$ ) were recorded at the baseline and at the all recall appointments during one year.

Results: All periodontal parameters showed a significant increase from the baseline to the first recall appointment for either group $(P<0,01)$. Group 2 had significantly lower PI, GI and BOP values than Group 1 at all recall appointments $(P<0,01)$.

Conclusions: This study emphasized that periodontal recall program consisting of four-week intervals seemed to be more successful than the recall program consisting of three-month intervals in terms of periodontal health of patients undergoing fixed orthodontic treatment.

Key words: Fixed Orthodontics, Oral Hygiene, Periodontal Recall, Listerine

\section{öz}

Amaç: Bu çalışmanın amacı iki farklı periodontal takip programının, sabit ortodontik tedavi gören hastaların dişeti sağlığı üzerindeki etkilerini karşılaştırmaktır.

Gereç ve Yöntem: Ortodontik tedavi gören 54 hasta (25 kadın and 29 erkek, ortalama yaş: 15,19 $\pm 0,4$ yıl) Grup 1 ve Grup 2 olarak iki eşit gruba ayrıldı. Dört haftalık aralıklardan oluşan periodontal takip programı için Grup 2 seçilirken, Grup 1 için üç aylık aralıklardan oluşan periodontal takip programı seçildi. Periodontal parametreler (Plak İndeksi, Gingival İndeks ve Sondlamada Kanama) başlangıçta ve 1 yıl boyunca tüm takip randevularında kaydedildi.

Bulgular: Her iki grupta da başlangıçtan ilk takip randevusuna kadar tüm periodontal parametrelerde anlamlı artış gözlendi $(P<0,01)$. Grup 2'deki plak indeksi, gingival indeks ve sondlamada kanama Grup 1'e göre tüm takip randevularında anlamlı düzeyde düşüktü $(P<0,01)$.

Sonuç: Bu çalışma ortodontik tedavi gören hastalarda periodontal sağlık yönünden dört haftalık aralıkları içeren periodontal takip programının üç aylık aralıklarla takip edilen programa göre daha başarılı olduğunu vurgulamaktadır.

Anahtar Kelimeler: Sabit ortodontik tedavi, Oral hijyen, Periodontal takip, Listerin

\footnotetext{
${ }^{*}$ Department of Orthodontics, Faculty of Dentistry, İnönü University, Malatya.

${ }^{* *}$ Oral and Dental Health Center, Rize.

*** Department of Periodontology, Faculty of Dentistry, Recep Tayyip Erdoğan University, Rize.
} 


\section{INTRODUCTION}

Alignment of the crowded teeth with orthodontic treatment contributes in maintaining the periodontal health by facilitating plaque control during daily individual oral hygiene procedures. ${ }^{1-3}$ Unfortunately, various appliances, especially fixed orthodontic appliances, create the plaque retention areas, which complicate the plaque control and result in inflammatory periodontal diseases. ${ }^{4-6}$ It was frequently observed that patients who were treated with fixed orthodontic appliances had also white spot lesions $^{7,8}$ and decays in addition to gingivitis. ${ }^{9}$

In the literature, there are many studies aimed to reveal the most suitable oral care protocol, brushing technique and cleaning tools for increasing or keeping the oral hygiene motivation level of the patients undergoing fixed orthodontic treatment. ${ }^{10-29}$ It is noted that the major importance in the long-term success is not the content of oral care but rather it is to provide sustainability of the motivation level in the long-term suitably by patients. ${ }^{10,13}$ This situation indicates the importance of effective communication among the patient, parents, orthodontist and periodontist.

Therefore, this study aimed to evaluate the possible effects of the frequency of periodontal recall appointments on the plaque control and gingival health of patients undergoing fixed orthodontic treatment.

\section{MATERIALS AND METHODS}

This study included fifty-four adolescents (25 female and 29 male healthy children, mean age is $15,19 \pm 0,4$ years) undergoing for fixed orthodontic treatment in Atatürk University Faculty of Dentistry, Department of Orthodontics. The inclusion criteria of this study were: to be between the age of $12-18$, to have permanent dentition and not to have any periodontal diseases; the exclusion criteria were: not to have any physical or mental handicap and not to have cleft palate or lip. The periodontal treatments of all patients were completed a month before the beginning of the orthodontic treatment. The patients were randomly divided into two groups. Group 1 (13 females and 14 males, mean age was 15,29 $\pm 0,4$ years) was selected for the periodontal recall program which will be carried out in a three-month interval, and Group 2 (12 females and 15 males, mean age was $15,09 \pm 0,4$ years) was selected for the periodontal recall program which will be conducted in a month interval. After the placement of the fixed orthodontic appliances, standardized oral hygiene education was given. Following the verbal and applied education on the model (with fixed appliances), the patients were made to practice toward the mirror by the doctor. Similar brushing technique (Bass technique), orthodontic toothbrush (Oral-B Laboratories, Inc., Redwood City, California, USA), interdental toothbrush (G.U.M. bi direction, $0,9 \mathrm{~mm}$ or $1,2 \mathrm{~mm}$, Sunstar Americas, Inc., Chicago, USA), and mouth rinse (Listerine orange, Johnson \& Johnson Healthcare Products Division of McNEIL-PPC, Inc., Somerset County, New Jersey, USA) were recommended to the all patients for daily oral hygiene practices. All patients were informed about brushing and interdental cleaning, and following, the usage of mouth rinse about 30 seconds twice a day. In order to support the oral hygiene motivation efforts, the image of microbial dental plaque under the phase-contrast microscope was shown to the patients at baseline, $3^{\text {rd }}, 6^{\text {th }}, 9^{\text {th }}$ and $12^{\text {th }}$ months. The dynamic life of the bacterium on microbial dental plaque was displayed to the patients.

\section{Periodontal Recording}

The periodontal assessment of the participants was performed by two trained and calibrated examiners (OK, TA) at six sites per tooth (mesiobuccal, buccal, disto-buccal, mesio-lingual, lingual, and disto-lingual) with a Williams probe with Michigan markings (Hu-Friedy, Chicago, IL.) The periodontal recordings included plaque index ${ }^{30}$ (PI) gingival index $^{31}$ (GI) and bleeding on probing ${ }^{32}$ (BOP). Baseline measurements were recorded a month before the placement of the fixed orthodontic appliances. Periodontal recall appointments were planned just before the orthodontic treatment appointments. During all of the recall appointments, firstly, PI, GI and BOP values were recorded. After that, it was aimed to increase patient's motivation level and the oral hygiene education procedure was repeated. Intra examiner variability in using the periodontal examination criteria was tested by performing duplicate examinations on 16 randomly selected participants. Agreement was $91 \%$ for PI and $\% 90$ for BOP. 


\section{Statistical Method}

For statistical analysis, the differences between the groups were tested by Mann-Whitney $U$ Test and the differences within the group were tested by Paired Samples Student Test. Statistical analysis of the study data was achieved by a software program (SPSS 17.0 for Windows, IBM, Chicago, IL). The data were presented as mean \pm standard error (SD), and $P$ value was set at 0.05 for all tests.

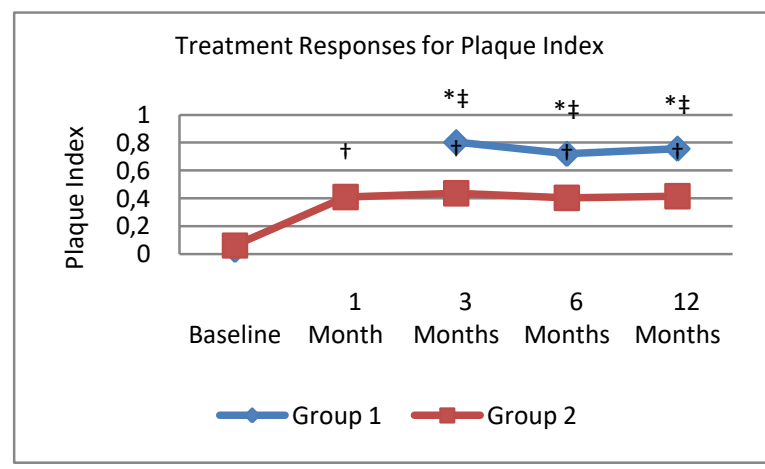

Figure 1. Treatment responses for plaque index. Significantly differences from baseline for group $1 . * \mathrm{P}<.01$ Significantly differences from baseline for group $2 .+P<.01$ Significant difference between groups. $\neq \mathrm{P}<.01$

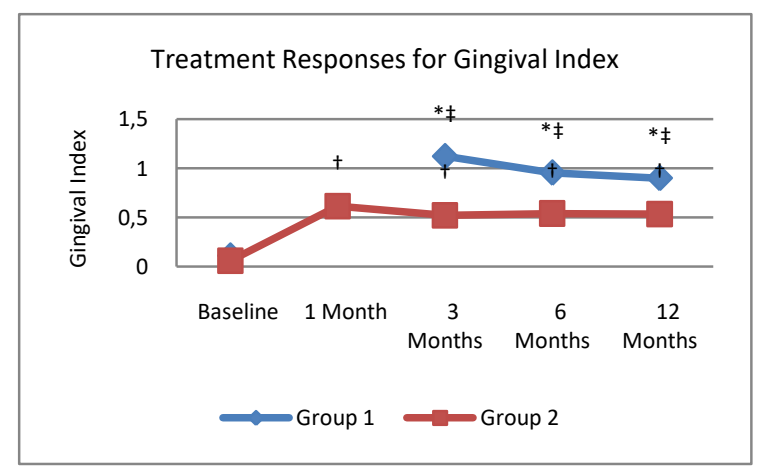

Figure 2. Treatment responses for gingival index.

Significantly differences from baseline for group $1 . * \mathrm{P}<.01$ Significantly differences from baseline for group $2 .+P<.01$ Significant difference between groups. $\neq \mathrm{P}<.01$

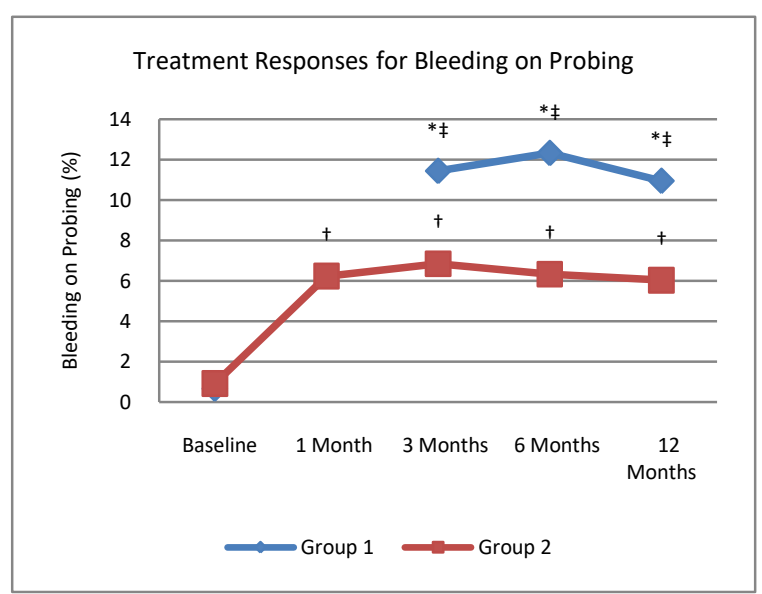

Figure 3. Treatment responses for bleeding on probing. Significantly differences from baseline for group $1 . * \mathrm{P}<.01$ Significantly differences from baseline for group 2 . $+P<.01$ Significant difference between groups. $\neq \mathrm{P}<.01$

\section{RESULTS}

All of the enrolled patients completed the study. The age and gender distributions of groups are presented in Table 1 ( $P>0.05)$. Table 2 shows PI, GI and BOP values for each group at the five specified time points. At intra group examination, it was observed that all index values increased significantly from the baseline period to third-month for Group 1 $(P<0.01)$ and to the first month for Group $2(P<0.01)$. There was no difference in any of the index values at later time points for each group. At inter group examination, no significant difference was observed between the groups at baseline for PI, GI and BOP values $(P>0.05)$. At the third-month, the participants of Group 2 had significantly lower mean PI $(P<0.01)$, GI $(P<0.01)$ and BOP $(P<0.01)$ values than the participants of Group 1. Mean PI, GI and BOP values remained significantly different between the groups at 6 -month $(P<0.01)$ and at 12 -month $(P<0.01)$.

Table 1. The Distribution of the Age (mean \pm SD) and Gender of the Study Groups.

\begin{tabular}{|l|l|l|c|c|c|}
\hline Groups & Gender & $\mathbf{n}$ & $\begin{array}{c}\text { Age } \\
\text { (mean } \pm \\
\text { SD) }\end{array}$ & $\mathbf{n}$ & $\begin{array}{c}\text { Age } \\
\text { (mean } \pm \\
\text { SD) }\end{array}$ \\
\hline Group & Male & 14 & $15.41 \pm 0.4$ & 27 & $15.29 \pm 0.4$ \\
$\mathbf{1}$ & Female & 13 & $15.17 \pm 0.5$ & & \\
\hline Group & Male & 15 & $14.92 \pm 0.3$ & 27 & $15.09 \pm 0.4$ \\
$\mathbf{2}$ & Female & 12 & $15.26 \pm 0.3$ & & \\
\hline
\end{tabular}

Data are mean $\pm S D$ for age, $P>.05$ 
Table 2. PI, GI and BOP values of the each Group at Baseline, 1 Month (only for Group 2), 3 Months, 6 Months and 12 Months.

\begin{tabular}{|l|c|c|c|}
\hline & $\begin{array}{c}\text { Group 1 } \\
\text { (n:26) }\end{array}$ & $\begin{array}{c}\text { Group 2 } \\
\text { (n:26) }\end{array}$ & $\begin{array}{c}\text { Significance } \\
\text { Between } \\
\text { Groups }\end{array}$ \\
\hline $\begin{array}{l}\text { Plaque Index } \\
\text { Baseline }\end{array}$ & $0.030 \pm 0.020$ & $0.032 \pm 0.015$ & \\
1 Month & & $0.410 \pm 0.205 \dagger$ & $*$ \\
3 Months & $0.803 \pm 0.176 \dagger$ & $0.436 \pm 0.190 \dagger$ & $*$ \\
6 Months & $0.720 \pm 0.202 \dagger$ & $0.404 \pm 0.202 \dagger$ & $*$ \\
12 Months & $0.757 \pm 0.276 \dagger$ & $0.416 \pm 0.193 \dagger$ & $*$ \\
\hline Gingival & & & \\
Index & $0.073 \pm 0.042$ & $0.061 \pm 0.015$ & \\
Baseline & & $0.615 \pm 0.214 \dagger$ & $*$ \\
1 Month & $1.122 \pm 0.288 \dagger$ & $0.522 \pm 0.225 \dagger$ & $*$ \\
3 Months & $0.956 \pm 0.275 \dagger$ & $0.541 \pm 0.230 \dagger$ & $*$ \\
6 Months & $0.901 \pm 0.308 \dagger$ & $0.535 \pm 0.204 \dagger$ & \\
12 Months & & & \\
\hline Bleding on & & & \\
Probing (\%) & $0.652 \pm 0.308$ & $0.714 \pm 0.310$ & $*$ \\
Baseline & & $6.233 \pm 4.422 \dagger$ & \\
1 Month & $11.435 \pm 5.366 \dagger$ & $6.837 \pm 4.133 \dagger$ & $*$ \\
3 Months & $12.322 \pm 4.886 \dagger$ & $6.322 \pm 3.876 \dagger$ & $*$ \\
6 Months & $10.944 \pm 5.310 \dagger$ & $6.028 \pm 4.565 \dagger$ & $*$ \\
12 Months & & & \\
\hline
\end{tabular}

Data are mean \pm SD

Significant differences within groups, $+p<.01$

Significant difference between groups, $* p<.01$

\section{DISCUSSION}

It was stated that the plaque control was weaker but the gingivitis incidence was higher in adolescents than adults. ${ }^{4-6}$ In addition to this, the orthodontic treatment patients are usually adolescents. Thus the participants of our study consisted of adolescents who were at the ages of 1218. Orthodontic appliances, especially the fixed orthodontic appliances, accelerate gingivitis, white spot lesions and the progress of decaying by means of making the plaque accumulation easier but the plaque control more difficult. ${ }^{4-9}$ When the inadequacy in the plaque control has a chronic course, this causes hyperplasic gingival enlargements. Heading for amid brackets, hyperplasic gingival tissue makes the plaque control even more difficult. In order to prevent these problems, many methods were proposed, and all of these methods were found, more or less, successful. ${ }^{10-}$ ${ }^{29}$ It might be possible to care for periodontal health as well as to minimize the progress of decaying by effectively and continuously implementing the above mentioned oral care methods, which are regarded as relatively difficult and/or time-consuming by orthodontic patients. In this context, it is clear that keeping patient motivation at the high level is important. At fixed orthodontic patients, it was noted that the periodontal recall consisting of four-week intervals was effective in eliciting a significant decrease in PI, GI and BPO scores ${ }^{11}$ and preventing the gingival enlargements. ${ }^{10}$ Demineralisation which was an another problem around orthodontic brackets can occur in a short time of 4 weeks and this can be prevent by good oral hygiene instructions. Alkadhi et al. stated that PI and GI all significantly decreased after 4 weeks of using active reminders of oral hygiene instructions and this showed us the importance of four-week periodontal recall was enhanced the periodontal tissue health. ${ }^{33}$ In the literature, it was seen that there was no uniformity in terms of the frequency of the intervention in a prophylaxis regime and $\mathrm{OHI}$ frequency varied between 3 weeks and 4 months. ${ }^{34}$

The aim of our study was to evaluate the longterm possible effects of periodontal recall consisting of one-month or three-months intervals from the beginning of the fixed orthodontic treatment on gingival health. The observable increase in main PI, GI and BOP scores for both groups from the baseline to the first recall appointment may be related to the plaque retentive and cleaning complicating effects of orthodontic appliances. Our findings clearly shows that periodontal recall performed at intervals of one month increases plaque control and limits the inflammatory changes prominently support the findings of Yeung at al. ${ }^{11}$, and Huber et al. ${ }^{10}$.

Making the person watch the motile organisms in the plaque sample, which is taken from his/her own tooth surface, with the help of phase-contrast microscope, contributes to the person's motivation. Shulman et al. ${ }^{35}$ revealed that using a phase-contrast microscope with the aim of oral hygiene motivation, reduction in plaque amount can be maintained at significant levels for up to 7 months. Furthermore, Acharya et al. ${ }^{16}$ stated that the usage of phasecontrast microscope in patients undergoing fixed orthodontic treatment was significantly helpful in terms of keeping the patient motivation at a high level permanently. Bowen et al. mentioned that text messages, chair side motivational tests and phase contrast microscopy with conventional plaque control measures were improved oral hygiene compliance at 4 to 12 week intervals in orthodontic patients. ${ }^{36}$ Therefore, we used phase-contrast microscope in our

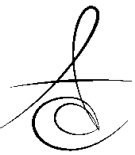


study with the aim of supporting our patient motivation efforts. Furthermore, Marini et al. indicated the importance of repeated oral hygiene instructions and motivations which were crucial in reducing PI scores at a follow up time of 4 weeks to 20 weeks. ${ }^{37}$

Some studies have pointed out that it is difficult to remove the plaque from or around the brackets and other orthodontic appliances completely and that it might be helpful for mechanical plaque control to be supported with chemical plaque control. ${ }^{38}$ Listerine, the essential oil containing mouthrinse, is effective especially on the supragingival plaque bacteria. ${ }^{39,40}$ The studies have shown that the usage of Listerine, in addition to toothbrush and dental floss, is effective on the prevention of gingivitis and halitosis. ${ }^{40}$ Moreover, Tufekci et al. ${ }^{28}$ state that the usage of Listerine, in addition to toothbrush and dental floss, is useful for preventing or reducing the progress of gingivitis and white spot lesions. Thus, we also recommend the usage of Listerine mouthrinse with the aim of supporting the daily plaque control of the patients. In another study, Sharma et al. investigated the possible efficacy of manual orthodontic toothbrushes, powered and sonic toothbrushes in controlling plaque, gingivitis and interdental bleeding in patients undergoing fixed orthodontic treatment and the relative comparative effectiveness was found to be similar for all the three brushes baseline to 4 and 8 weeks. ${ }^{41}$

The studies have shown that co-operation level of the orthodontic patients is affected by many factors such as the patient's age, sex, personality traits, socioeconomic condition and relationship with his/her parents. ${ }^{12,42}$ Whittle et al. ${ }^{43}$ stated that the children of the families with both parents pay more attention to the responsibilities for oral care than the children of the families with single parent, while Sergl ${ }^{44}$ revealed that the children, who are academically successful, pay more attention to the responsibilities for oral care than children, who are academically less successful. Demographic parameters of the participants apart from age and sex have not been evaluated and this was a limitation of our study. Besides, our study groups consisted of individuals, who were at the ages of 12-18 and whom fixed orthodontic treatment was planned for. For this reason, our findings might not be effective on children or adult individuals as well as on the individuals who were treated with removable appliances. Another limitation of our study was that one of the plaque indexes, which allows specifically evaluating the plaque quantity around fixed orthodontic appliances ${ }^{45}$, was not chosen. For the reason that our study was a long-time follow-up study, a plaque index, which is less time-consuming and frequently chosen in similar oriented studies ${ }^{30}$, was chosen.

\section{CONCLUSION}

There is a close relationship between the patients' motivation levels and the effectiveness of their daily oral care. In addition to this, the motivation level might decrease in time.

Periodontal recall program executed at fourweek intervals is more effective as compered to the program executed at three-month intervals, for the preservation of gingivall health of the adolescent patient undergoing fixed orthdodontic treatment in the long term.

Filiz Uslu: ORCID ID: 0000-0003-0958-261X

Tuba Köse: ORCID ID: 0000-0002-9240-551X

Oğuz Köse: ORCID ID: 0000-0002-0318-2458

\section{REFERENCES}

1. Feliu JL. Long-term benefits of orthodontic treatment on oral hygiene. Am J Orthod 1982;82:473-7.

2. Kessler M. Interrelationships between orthodontics and periodontics. Am J Orthod 1976;70:154-72.

3. Lusterman EA. Clinical significance of periodontic orthodontic interrelationships. NY State Dent J 1974;40:147-56.

4. Alstad S, Zachrisson BU. Longitudinal study of periodontal condition associated with orthodontic treatment in adolescents. Am J Orthod 1979;76:277-86.

5. Boyd RL, Baumrind S. Periodontal consideration in the use of bonds or bands on molars in adolescents and adults. Angle Orthod 1992;62:117-26.

6. Hamp SE, Lundström F, Nyman S. Periodontal conditions in adolescents subjected to multiband orthodontic treatment with controlled oral hygiene. Eur J Orthod 1982; 4:77-86. 
7. Tufekci E, Dixon JS, Gunsolley JC, Lindauer SJ. Prevalence of white spot lesions during orthodontic treatment with fixed appliances. Angle Orthod 2011;81:206-10.

8. Øgaard B. White spot lesions during orthodontic treatment: mechanisms and fluoride preventive aspects. Semin Orthod 2008;14:183-93.

9. O'Reilly MM, Featherstone JDB. Demineralization and remineralization around orthodontic appliances: an in vivo study. Am J Orthod Dentofacial Orthop 1987;92:33-40.

10. Huber SJ, Vernino AR, Nanda RS. Professional prophylaxis and its effect on the periodontium of full-banded orthodontic patients. Angle Orthod. 1972;42:26-34.

11. Yeung SC, Howell S, Fahey P. Oral hygiene program for orthodontic patients. Am J Orthod Dentofacial Orthop. 1989;96:208-13.

12. Albino JE, Lawrence SD, Lopes CE, Nash LB, Tedesco LA. Cooperation of adolescents in orthodontic treatment. J Behav Med 1991;14:5370.

13. Lees A, Rock WP. A comparison between written, verbal, and videotape oral hygiene instruction for patients with fixed appliances. J Orthod 2000; 27: 323-8.

14. Matic S, Ivanovic M, Mandic J, Nikolic P. Possibilities to prevent gingivitis during fixed orthodontic appliance therapy. Stom Glas S 2008;55:122-32

15. Al-Jewair TS, Suri S, Tompson BD. Predictors of adolescent compliance with oral hygiene instructions during two-arch multibracket fixed orthodontic treatment. Angle Orthod 2011;81:52531.

16. Acharya S, Goyal A, Utreja AK, Mohanty U. Effect of three different motivational techniques on oral hygiene and gingival health of patients undergoing multibracketed orthodontics. Angle Orthod 2011; 81: 884-8.

17. Pontier JP, Pine C, Jackson DL, Di Donato AK, Close J, Moore PA. Efficacy of a prebrushing rinse for orthodontic patients. Clin Prev Dent 1990; 12: 12-7.
18. Burch JG, Lanese R, Ngan P. A two-month study of the effects of oral irrigation and automatic toothbrush use in an adult orthodontic population with fixed appliances. Am J Orthod Dentofacial Orthop 1994;106:121-6.

19. Kilicoglu $H$, Yildirim M, Polater $H$. Comparison of the effectiveness of two types of toothbrushes on the oral hygiene of patients undergoing orthodontic treatment with fixed appliances. Am J Orthod Dentofacial Orthop 1997;111:591-4

20. Heasman P, Wilson Z, MacGregor I, Kelly P. Comparative study of electric and manual toothbrushes in patients with fixed orthodontic appliances. Am J Orthod Dentofacial Orthop 1998;114:45-9.

21. Ramaglia L, Sbordone L, Ciaglia RN, Barone A, Martina R. A clinical comparison of the efficacy and efficiency of two professional prophylaxis procedures in orthodontic patients. Eur J Orthod 1999; 21: 423-8.

22. Thienpont V, Dermaut LR, Van Maele G. Comparative study of 2 electric and 2 manual toothbrushes in patients with fixed orthodontic appliances. Am J Orthod Dentofacial Orthop 2001; 120: 353-60.

23. Hickman J, Millett DT, Sander L, Brown E, Love J. Powered vs manual tooth brushing in fixed appliance patients: a short term randomized clinical trial. Angle Orthod 2002;72:135-40.

24. Olympio KPK, Bardal PAP, de M Bastos JR, Buzalaf MAR. Effectiveness of a chlorhexidine dentrifrice in orthodontic patients: a randomized-controlled trial. J Clin Periodontol 2006;33:421-6.

25. Wang S, Yang $Y$, Chang $H$. The effect of an oral hygiene instruction intervention on plaque control by orthodontic patients. J Dent Sci 2007; 2:45-51.

26. Yetkin Ay Z, Sayın MO, Ozat Y, Goster T, Atilla AO, Bozkurt FY. Appropriate Oral Hygiene Motivation Method for Patients with Fixed Appliances. Angle Orthod 2007;77:1085-9.

27. Arici S, Alkan A, Arici N. Comparison of different toothbrushing protocols in poor-toothbrushing orthodontic patients. Eur J Orthod 2007;29:48892. 
28. Tufekci E, Casagrande ZA, Lindauer SJ, Fowler CE, Williams KT. Effectiveness of an Essential Oil Mouthrinse in Improving Oral Health in Orthodontic Patients. Angle Orthod 2008;78:294-8

29. Ay ZY, Esenlik E, Çağlar F. Effect of different oral hygiene motivation methods on halitosis levels of patients treated by fixed orthodontic therapy. ] Dent Fac Atatürk Uni 2013;23:307-12

30. Silness J, Löe H. Periodontal disease in pregnancy. II. Correlation between oral hygiene and oral condition. Acta Odontol Scand 1964;22:121-35.

31. Löe $H$. The gingival index, plaque index and the retention index systems. J Periodontol 1967;38:610-6.

32. Ainamo J, Bay I. Problems and proposals for recording gingivitis and plaque. Int Dent J 1975;25:229-35.

33. Alkadhi $\mathrm{OH}$, Zahid MN, Almanea RS, Althaqeb HK, Alharbi TH, Ajwa NM. The effect of using mobile applications for improving oral hygiene in patients with orthodontic fixed appliances: a randomised controlled trial. J Orthod. 2017;44:157-63.

34. Migliorati $M$, Isaia $L$, Cassaro $A$, Rivetti $A$, Silvestrini-Biavati F, Gastaldo L, Piccardo I, Dalessandri D, Silvestrini-Biavati A. Efficacy of professional hygiene and prophylaxis on preventing plaque increase in orthodontic patients with multibracket appliances: a systematic review. Eur J Orthod. 2015;37:297-307.

35. Shulman J. Clinical evaluation of the phase contrast microscope as a motivational aid in oral hygiene. J Am Dent Assoc 1976;92:759-65.

36. Bowen TB, Rinchuse DJ, Zullo T, DeMaria ME. The influence of text messaging on oral hygiene effectiveness. Angle Orthod. 2015;85:543-8.

37. Marini I, Bortolotti F, Parenti SI, Gatto MR, Bonetti GA. Combined effects of repeated oral hygiene motivation and type of toothbrush on orthodontic patients: a blind randomized clinical trial. Angle Orthod. 2014;84:896-901.

38. Boyd RL. Enhancing the value of orthodontic treatment: Incorporating effective preventive dentistry into treatment. Am J Orthod Dentofacial Orthop 2000;117:601-3.
39. Bauroth K, Charles CH, Mankodi SM, Simmons K, Zhao Q, Kumar LD. The efficacy of an essential oil antiseptic mouthrinse vs. dental floss in controlling interproximal gingivitis: a comparative study. J Am Dent Assoc 2003;134:359-65.

40. Fine $\mathrm{DH}$. Reducing bacteria in dental aerosols: preprocedural use of an antiseptic mouth rinse. J Am Dent Assoc 1993;124:56-8.

41. Sharma R, Trehan M, Sharma S, Jharwal V, Rathore N. Comparison of Effectiveness of Manual Orthodontic, Powered and Sonic Toothbrushes on Oral Hygiene of Fixed Orthodontic Patients. Int J Clin Pediatr Dent 2015;8:181-9.

42. Mehra T, Nanda RS, Sinha PK. Orthodontists' assessment and management of patient compliance. Angle Orthod 1998;68:115-22.

43. Whittle JG. Attendance patterns and dental health of parents and children. Community Dent Health 1993;10:235-42.

44. Sergl HG, Klages U, Pempera J. On the prediction of dentist-evaluated patient compliance in orthodontics. Eur J Orthod 1992;14:463-8.

45. Al-Anezi SA, Harradine NWT. Quantifying plaque during orthodontic treatment: A systematic review. Angle Orthod 2012;82:748-53.

\section{Yazışma Adresi}

Associate Professor Dr. Oğuz Köse, Department of Periodontology, Faculty of Dentistry, Recep Tayyip Erdoğan University, Rize, 53100, Turkey E-mail:dtoguzkose61@hotmail.com 